\title{
AN INVESTIGATION OF VARIOUS FACTORS WHICH AFFECT THE SEDIMENTATION RATE OF THE RED BLOOD CELLS ${ }^{1}$
}

By M. DOROTHY ROURKE AND E. D. PLASS

(From the Beth Israel Hospital, Boston, and the Department of Obstetrics and Gynecology, State University of Iovea)

(Received for publication March 26, 1929)

Since the work of Fahraeus, in 1921 (1), the phenomenon of the settling of the red corpuscles in blood to which an anticoagulant has been added has been studied intensively by biologists as well as by clinicians. The former have been interested chiefly in determining the mechanism whereby the settling rate of the cells is increased or diminished in certain physiological and pathological conditions, and in studying the various chemical and physical factors which may vary the rate; while the clinical investigators have attempted to evaluate the diagnostic and prognostic significance of observed changes in the rate of sedimentation. Preliminary to a renewed effort along clinical lines, we have carried out a series of experiments designed to show the effect which certain factors may have upon the settling rate.

The sedimentation tubes used in these experiments contained $\mathbf{1 . 0}$ cc. of blood, were $4.0 \mathrm{~mm}$. in diameter, were sealed flat at one end, and were graduated from 0 to $80 \mathrm{~mm}$. They were coated on the inside with a very thin layer of paraffin. All blood samples were collected without stasis and were manipulated entirely under oil.2

THE EFFECT OF VARIOUS ANTICOAGULANTS UPON THE RATE OF SEDIMENTATION

The precipitation of colloids of the suspensoid type by adsorption of an electrolyte and the stabilizing of an otherwise labile system by

${ }^{1}$ A portion of the experimental work was completed in 1926 at the Henry Ford Hospital, Detroit.

2 These tubes were $20 \mathrm{~mm}$. shorter than those finally decided upon and described for clinical use in the J. Clin. Invest., 1928, v, 531. 
a similar process are familiar phenomena. Fahraeus (1) noted that, if defibrinated horse blood is diluted with a 0.9 per cent solution of sodium chloride, the specific gravity and viscosity of which are less than that of the serum, the sedimentation rate of the erythrocytes is actually diminished. Furthermore, he showed that if as little as 0.025 gram of solid sodium chloride is added to $5.0 \mathrm{cc}$. of defibrinated horse blood, the sinking of the cells is decreased from 75 to $3 \mathrm{~mm}$. in 15 minutes, and that there occurs an increase in the negative charge on the corpuscles, proportional to the amount of sodium chloride added. In these instances, the suspension has been stabilized by addition of the electrolyte. Popper and Kreindler (2) have likewise shown the stabilizing effect of the addition of electrolytes to the blood. On the other hand, Linzenmeier (3) and Fahraeus (1) have both shown that the sedimentation rate increases if small amounts of lanthanum nitrate are added, and that when larger amounts of this salt are introduced the corpuscles of human blood become positively charged. Provided the magnitude of this charge is sufficiently large the system can be made stable. The precipitating effect of some salts and the stabilizing effect of others is probably referable to the valency of the cation, as pointed out by Oliver and Barnard (4).

Because of the changes that added electrolytes may bring about in the stability of the blood, it seemed advisable to determine the effect of the different anticoagulants in common use, and to adopt for clinical work a substance which has no effect upon the suspension stability other than keeping the blood from clotting. Sodium fluoride $(50 \mathrm{mgm}$. per $5.0 \mathrm{cc}$. of blood), potassium oxalate $(14 \mathrm{mgm}$. per $5.0 \mathrm{cc}$. of blood), and potassium citrate $(10 \mathrm{mgm}$. per $5.0 \mathrm{cc}$. of blood) were taken as representative of the inorganic anticoagulants, and were compared with each other and with heparin $(1 \mathrm{mgm}$. per $5.0 \mathrm{cc}$. of blood), the organic anticoagulant obtained from liver substance. In every instance the concentration of anticoagulant was sufficient to prevent clotting during the period of the experiment.

Chart 1 presents graphically the varied rates of settling found when separate specimens of the same blood were treated with the different anticoagulants in the amounts indicated above. With the settling most rapid in the heparinated sample, it is apparent that the rate of sedimentation in the others varies inversely with the concen- 
tration of salt necessary to prevent coagulation. Similar differences were noted in several other experiments of the same nature. No attempt was made to determine whether the slowing varies mathematically with the concentration of the salts.

In the Linzenmeier (3) method employed by a great many investigators for the clinical determination of the sedimentation rate, one part of 5 per cent sodium citrate is used to four parts of blood. Such

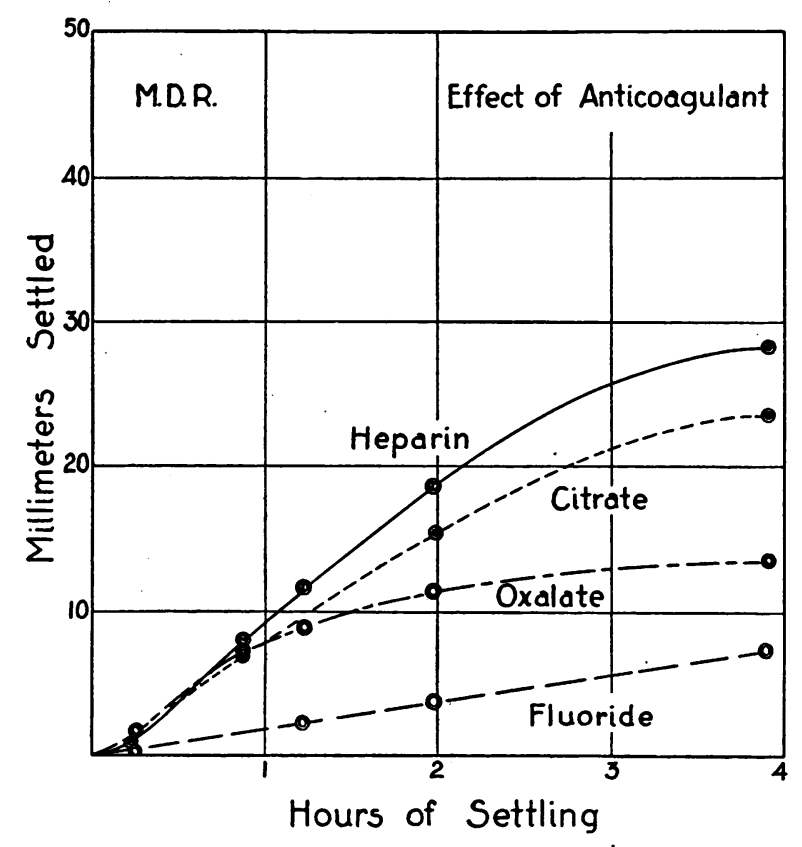

Chart 1. The Effect of Different Anticoagulants upon the Sedimentation Rate of Blood Celis

a mixture was compared with blood treated with 7dry potassium citrate $(10 \mathrm{mgm}$. per $5 \mathrm{cc}$. of blood) and with heparin $(1 \mathrm{mgm}$. per 5 cc. of blood). The results are shown in chart 2. The diluted blood (III on the curve) settled more slowly even than the blood treated with dry citrate. In the diluted specimen, the concentration of citrate was equal to $50 \mathrm{mgm}$. in $5 \mathrm{cc}$. of blood, a fact which undoubtedly explains the slower settling. The dilution itself would increase 
the rate, so that the real effect of the increased salt concentration is actually much greater than is apparent.

It now became essential to learn whether heparin has some active influence toward hastening the settling, or whether the results obtained when this substance is used represent the sedimentation rate of untreated blood. It seemed reasonable to assume that if a certain concentration of any anticoagulant affects the stability of the blood,

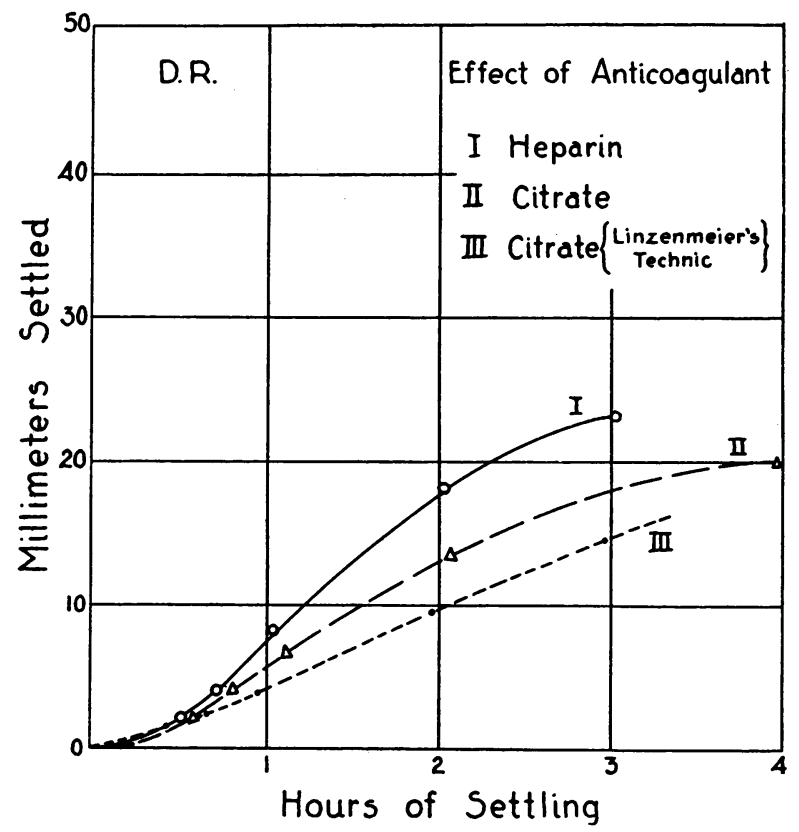

Chart 2. The Efrect upon the Sedmentation Rate of Solid Citrate and Citrate Solution as Compared with the Effect of Heparin

a greater concentration should produce a more marked effect in the same direction. Doubling the concentration of the oxalate, the citrate, or the fluoride always produces an appreciably greater slowing of the sedimentation rate, whereas, even when the concentration of heparin is tripled or quadrupled there is no effect upon the rate of settling (chart 3).

It is obvious that the concentration in the plasma of the added anticoagulant will be less in those bloods with high plasma volume 
percentages than in those with higher hematocrits. For this reason, the stabilizing effect of the electrolyte anticoagulants varies from one blood to another, and the results are not strictly comparable. Heparin should then be the preferred anticoagulant for this type of

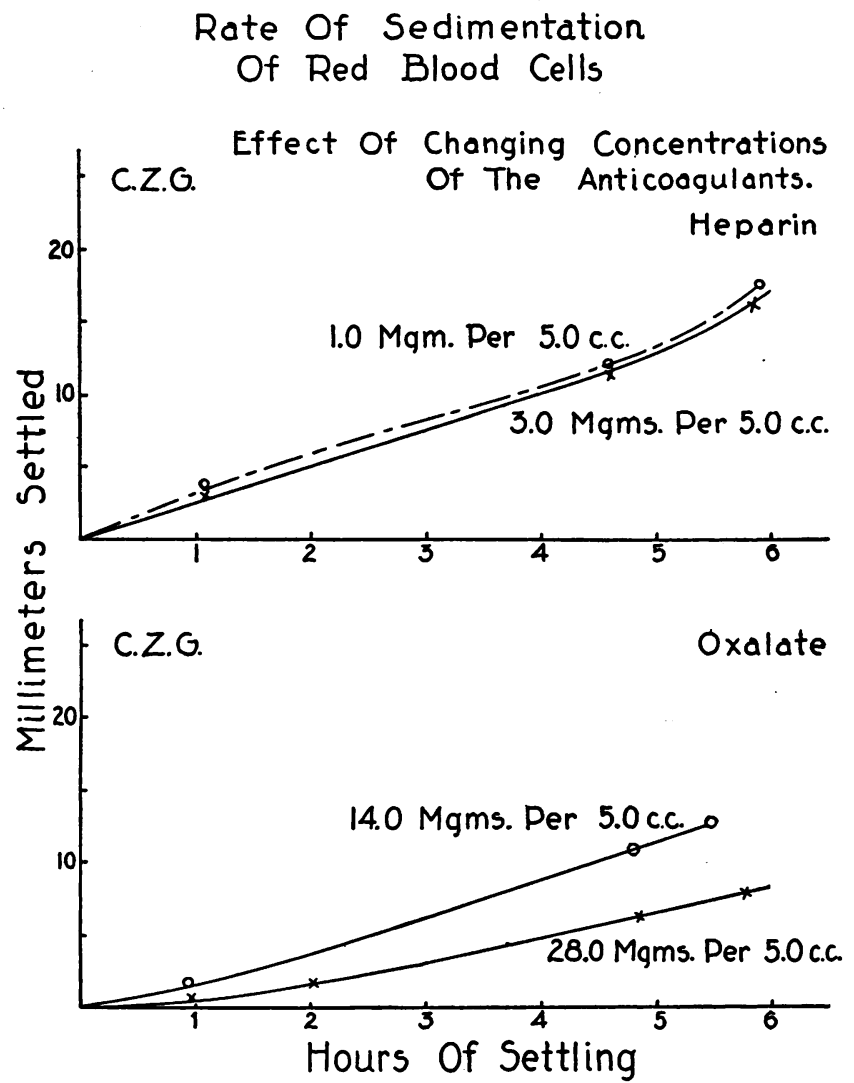

Chart 3. The Effect upon the Sedmentation Rate of Increasing the Concentration of Different Anticoagulants (Oxalate and Heparin)

work, for this substance even in considerable concentration does not affect the sedimentation rate. Heparin was, therefore, used as the anticoagulant in all the experiments reported below.

Absolute proof that heparin does not affect the sedimentation rate was not easy, but finally we were fortunate enough to secure a 
sample of blood from a hemophiliac, whose clotting time was over five hours. Chart 4 shows the sedimentation curves in two specimens of this blood, the one with no anticoagulant and the other with heparin (1 mgm. per $5 \mathrm{cc}$. of blood). Since there was no demonstrable difference in the settling rates of the two samples, we were forced to the conclusion that heparinated blood settles more rapidly than blood treated with fluoride, citrate, or oxalate not because heparin accelerates

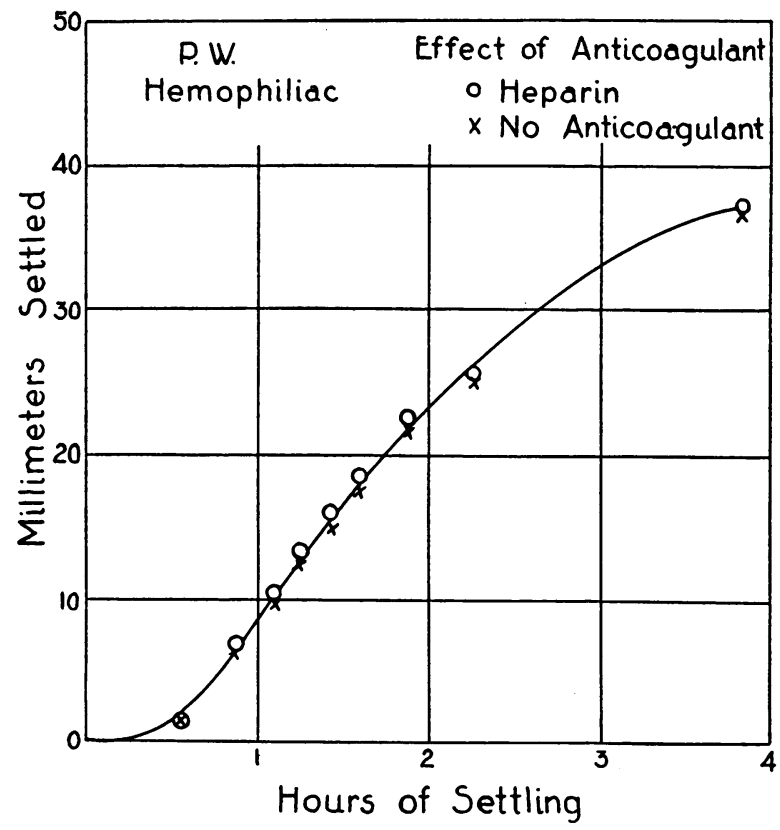

Chart 4. No Effect upon the Sedmentation Rate of Hemophiliac Blood When HeParin Is AdDED

settling, but solely because it has no appreciable effect, whereas the electrolyte anticoagulants produce a definite slowing.

CHANGES IN THE STABILITY OF THE BLOOD AFTER STANDING AT ROOM TEMPERATURES

Pohle (5) states that if blood is allowed to stand and is then reshaken, the sedimentation velocity is rather markedly accelerated as compared with freshly drawn blood. Westergren (6), however, 
found that preserving blood for several hours at room temperature does not materially affect its settling velocity, but that after twentyfour hours standing the rate is slowed. Fahraeus (1), working with defibrinated horse blood reports that a specimen may be allowed to. stand at room temperature for as long as seven hours without changing

TABLE 1

Heparin-our technic

\begin{tabular}{|c|c|c|c|c|c|c|c|c|}
\hline \multirow{2}{*}{$\begin{array}{c}\text { Freshly } \\
\text { drawn }\end{array}$} & \multicolumn{8}{|c|}{ Millimeters settled in one hour after standing } \\
\hline & 1 hour & 2 hours & 3 hours & 4 hours & 5 hours & 6 hours & 7 hours & 8 hours \\
\hline 42 & & 41 & & 37 & & 36 & & 33 \\
\hline 44 & 44 & 43 & 44 & & & & & \\
\hline 40 & & 40 & 39 & 40 & 40 & & & \\
\hline 39 & & 39 & 39 & 39 & 38 & & & \\
\hline 35 & & 35 & 33 & 35 & & & & \\
\hline 48 & & 46 & 46 & 46 & 46 & & & \\
\hline 19 & & 20 & & 21 & & 21 & & 22 \\
\hline 8 & & 7 & & 8 & & 8 & & 13 \\
\hline 6 & & 5 & & 7 & & 6 & & 6 \\
\hline 5 & & 5 & & 5 & & 6 & & 6 \\
\hline
\end{tabular}

TABLE 2

Sodium citrate solution-Linzenmeier's technic

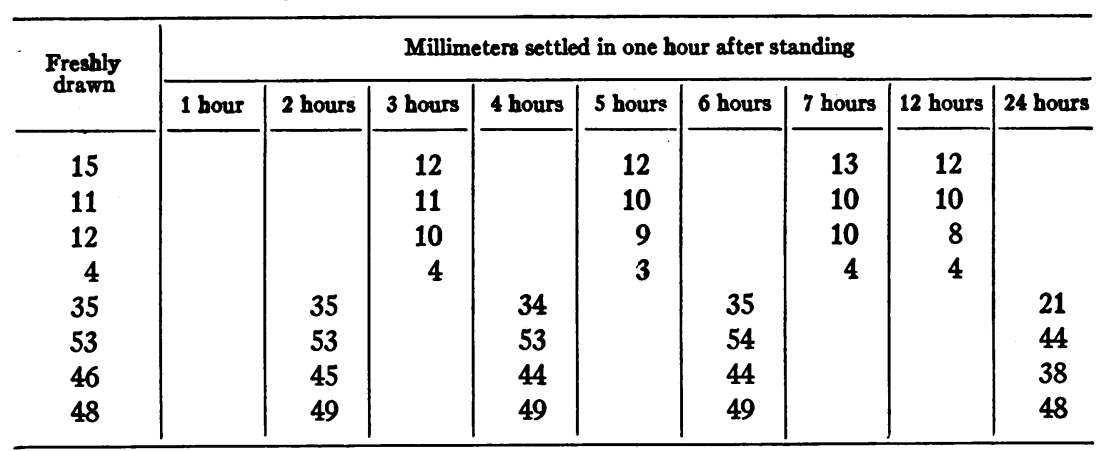

the amount of rouleau formation or the sedimentation velocity, but that when such blood is kept at higher temperatures (up to $58^{\circ} \mathrm{C}$.) rouleau formation is diminished, with a minimum at $42^{\circ} \mathrm{C}$. When he allowed a sample of oxalated blood to stand for 5 hours at $28^{\circ} \mathrm{C}$. and another similar sample at $18^{\circ} \mathrm{C}$. for the same period, the former 
settled more slowly. Wiltshire (7) has shown that oxalated human plasma loses more and more of its aggregating power on standing at room temperature. Obviously, it is of importance to learn definitely how much time may elapse between the collection of blood and the completion of the sedimentation test without any sacrifice of accuracy.

The following experiments were performed to measure changes in stability on standing with our method of preventing coagulation with heparin, as well as with Linzenmeier's method using one volume of 5 per cent sodium citrate to four volumes of blood. The bloods stood at temperatures of $22^{\circ}$ to $25^{\circ} \mathrm{C}$. and settling took place at the same temperatures.

Blood tends to become more stable on standing, but within the period of a working day the changes are usually insignificant, while after twenty-four hours at room temperature a considerable slowing of the sedimentation rate is usually observed. The effects of heparin and sodium citrate solution are practically the same.

Such results lead us to conclude that, for clinical purposes, blood sedimentation determinations may be postponed for some hours (6 to 12) after the blood is drawn without any considerable loss of accuracy, but that standing for a longer period may lead to serious errors by slowing the settling rate.

We are at a loss to explain why our results and Westergren's do not agree with those of Pohle, for we have found the reaction completely reversible within the time limits noted. Our blood samples were manipulated entirely under oil, but since Westergren does not state that he took a similar precaution, it seems doubtful whether that factor can explain the varied results.

THE EFFECT ON THE RATE OF SEDIMENTATION OF CENTRIFUGING AND REMIXING THE CELLS AND PLASMA

It was necessary in some of our experimental work to centrifuge the blood and later remix cells and plasma for a second determination of the sedimentation rate. To determine whether such manipulations have any effect upon the settling velocity, several specimens were treated in this way and the sedimentation rates compared with those of the original samples.

Experiment 1. E. L. M., normal young woman. A specimen was 
set up at once for determination of the sedimentation rate and the remainder immediately centrifuged for 20 minutes at 2500 r.p.m. This latter specimen was then remixed and the rate measured. The settling curves for the two specimens are identical. (See chart 5.)

Experiment 2. Dog A. Distemper. The blood was treated as in experiment 1 and the settling curves are identical (chart 5). It is

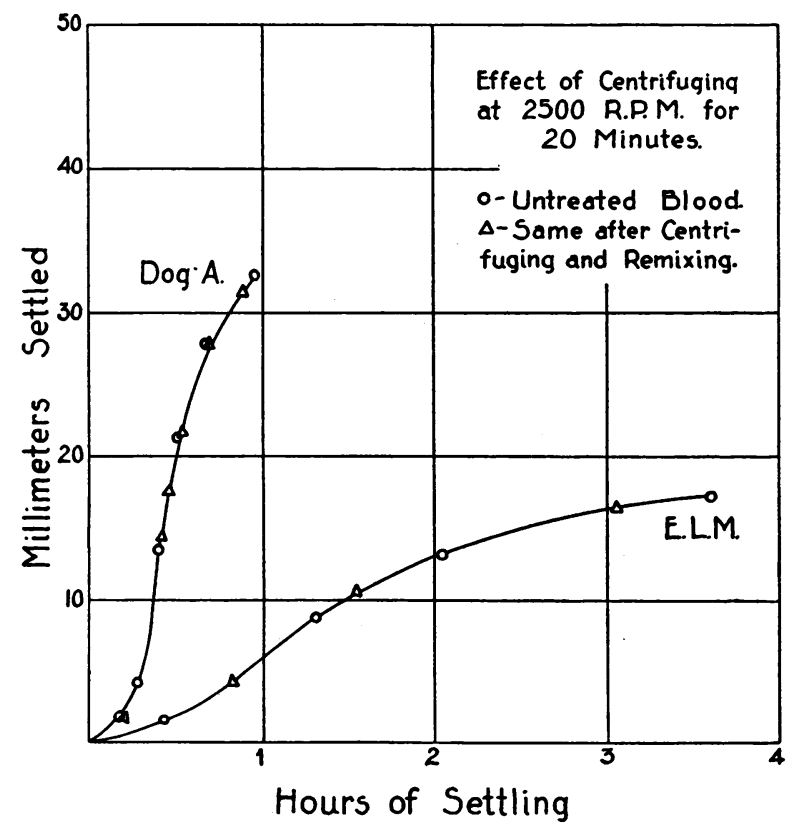

Chart 5. No Effect upon the Sedimentation Rate after Centrifuging Blood For 20 Minutes at 2500 R.P.M. AND REMIXING

important to note that rapidly-settling bloods are as reversible after centrifuging as are normal bloods.

Experiment 3. M. D. R., normal young woman. The blood was treated as in experiment 1 , except that after centrifuging the second sample and before remixing, the blood was allowed to stand for two hours at room temperature. The untreated specimen settled $14 \mathrm{~mm}$. in one hour, while the other settled $15 \mathrm{~mm}$.- an insignificant difference.

We have done other experiments of this character as well as a 
large number in which the blood was centrifuged at 1000 r.p.m. for 5 minutes, and in every instance the rate was the same as in the untreated sample.

These experiments show that after centrifuging for as long as 20 minutes at 2500 r.p.m. the stability of the remixed blood is not different from that of the freshly-drawn sample. Furthermore, it is indicated that the process of aggregation can be reversed by mechanical agitation. Were this not so, the sedimentation rate of the remixed centrifuged samples would have been more rapid in the first half-hour period, where the slope of the curve is small in freshly-drawn blood, because of the time necessary for aggregation to reach a maximum.

THE EFFECT OF BLOOD DILUTION UPON THE SEDIMENTATION RATE

By diminishing the number of particles in a suspension, the mean free path of such particles becomes greater, and consequently the rate at which the particles settle is increased. In blood, the sedimentation rate of the erythrocytes is roughly, inversely proportional to the cell volume, provided other factors are unchanged. This fact has already been emphasized by Fahraeus (1), DeCourcy (8), Guthmann and Schneider (9):, Gram (10), Bönniger and Herrmann (11), Rubin and Smith (12); and Hubbard and Geiger (13).

The sedimentation rate was determined upon part of the sample as drawn, and the remaining blood was centrifuged, the plasma and cells being used to make up specimens of different cell volumes as desired. The settling curves of these dilutions were then obtained and the final cell volumes determined by spinning at 2500 r.p.m. for 20 minutes.

The results of two such experiments appear in charts 6 and 7 where the effect of varying the cell volume by the addition of cells or plasma from the same samples of blood is shown graphically. It is evident that when the cell volume is reduced the rate of settling is increased.

In chart 8 , the millimeters settled in one hour are plotted against the cell volume, the numbers on the individual curves referring to separate experiments. It becomes evident that the function of the change due to dilution is practically a straight line in the range where neither packing nor primary aggregation is a prominent factor. 
It is very important, therefore, that the result of a sedimentation test should not be interpreted in terms of infection or of other tissue damage without consideration being paid to the concentration of the blood (cell volume).

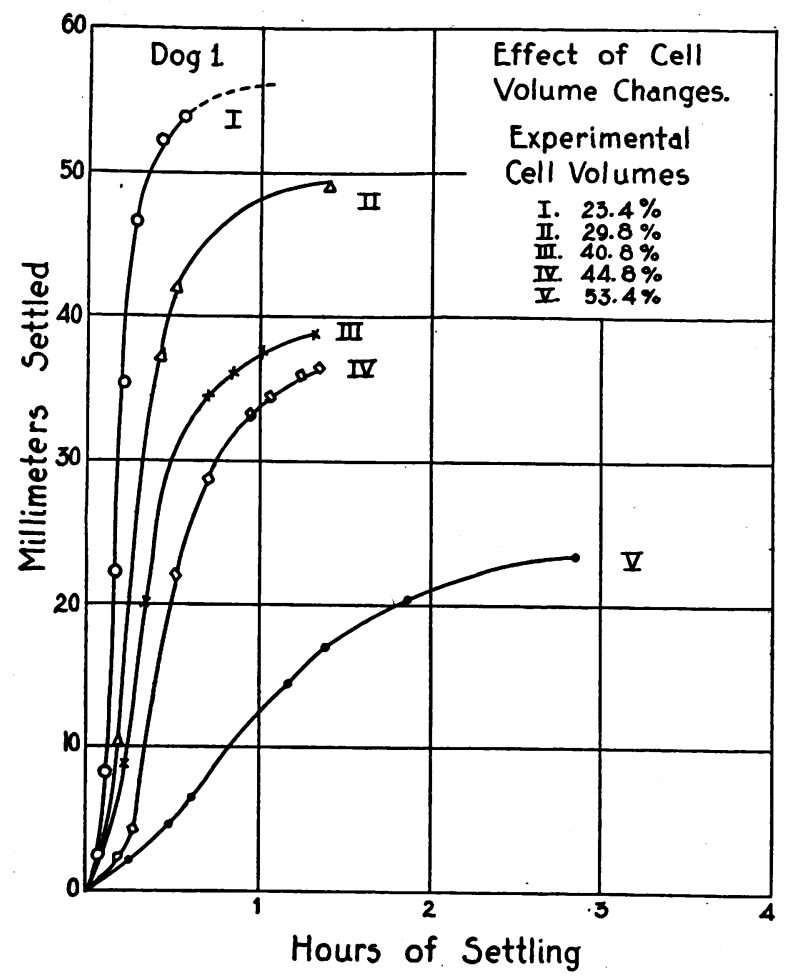

Chart 6. The Effect upon the Sedmentation Rate of a Rapidiy Settuing Blood Produced by Changing the Cell Volume

THE EFFECT OF AERATION OF THE BLOOD UPON THE SEDIMENTATION RATE

Popper and Kreindler (2), using Westergren's (14) technic, determined the sedimentation rates upon both arterial and venous bloods, and found no appreciable difference in four cases. Ito (15) has determined the sedimentation rates (Linzenmeier's method) of the blood after varying the carbon dioxide and oxygen contents within wide 
limits. In a typical experiment reducing the carbon dioxide content from 69 to 7 per cent increased the sedimentation rate from 20 to 22 $\mathrm{mm}$. in one hour, while increasing the oxygen content from 6 to 16 per cent increased the settling from 9 to $11 \mathrm{~mm}$. in one hour. Although these changes are very small they are consistent with several other

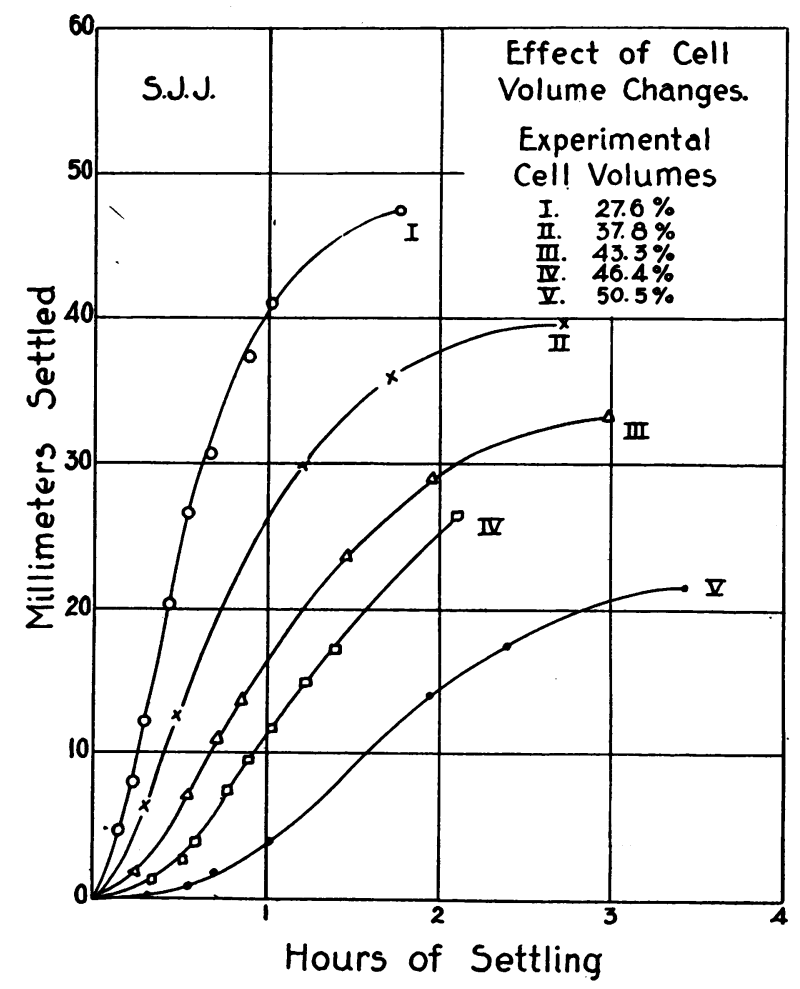

Chart 7. The Effect upon the Sedmentation Rate of a Slowly Settuing Blood Produced by Changing the Cell Volume

experiments recorded by this author. It would seem that simple aeration should produce only insignificant variations.

Our experimental procedure was as follows: Four cubic centimeters of blood were drawn from an arm vein under oil, using heparin as the anticoagulant, and the sedimentation rate was determined as usual on one cubic centimeter. Two cubic centimeters of the same blood were transferred to a paraffin-coated, 25 cc. Erlenmeyer flask, 
and agitated by rotating until the blood had become bright scarlet in color, after which its sedimentation rate was determined by the usual procedure. The time of reading was varied so that packing was not a factor.

The results of this study are in accord with what might be expected from the experiments of Popper and Kreindler (2) $b$ and of Ito (15).

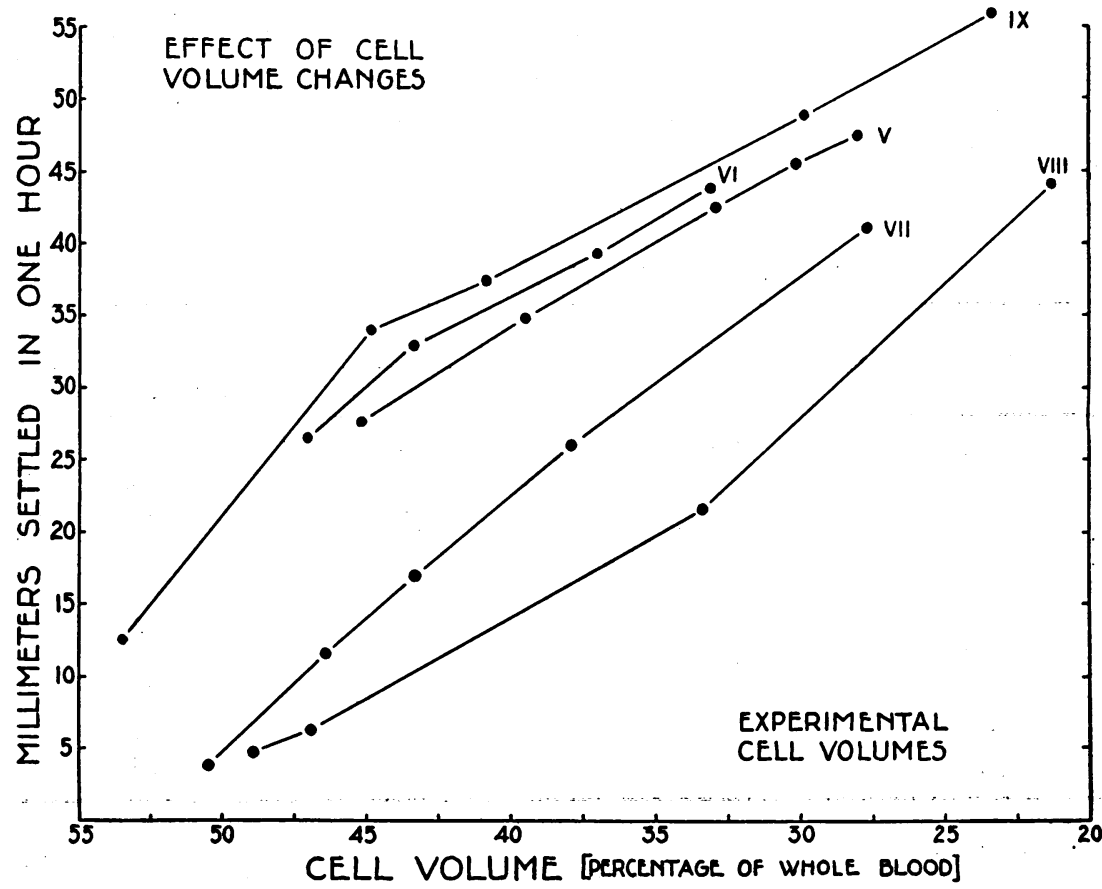

Chart 8. The Minlmeters Settled in One Hour Plotted against the Celi Volume

Five experiments in which the cell volume was artificially regulated

We conclude that the sedimentation rate is not appreciably affected by aeration or by loss of carbon dioxide, and that for practical clinical purposes collection under oil is not necessary, although this precaution would seem indicated where unusual accuracy is desirable. This conclusion would seem applicable to both slowly and rapidly settling bloods. 
THE EFFECT OF TEMPERATURE UPON THE SEDIMENTATION RATE

DeCourcy (8), using the Linzenmeier technic, determined the sedimentation rates of various blood samples at $6^{\circ}, 18^{\circ}$, and $37^{\circ} \mathrm{C}$. and concluded that while there was only a slightly increased rapidity of settling between $6^{\circ}$ and $18^{\circ} \mathrm{C}$., there was a considerable increase between $18^{\circ}$ and $37^{\circ} \mathrm{C}$. Westergren (6) shows graphically the variations in sedimentation rates at different temperatures, $14^{\circ}$ to $25^{\circ} \mathrm{C}$., of bloods settling with various speeds, and suggests the use of similar curves for correctional purposes. He also found that the effect of an increase in temperature is smaller with slowly settling

TABLE 3

The effect of aeration of the blood upon the sedimentation rate

\begin{tabular}{c|c|c|c}
\hline \multirow{2}{*}{ Blood number } & Time settled & \multicolumn{2}{|c}{ Millimeters settled } \\
\cline { 2 - 3 } & & Sample as drawn & Aerated sample \\
\hline 1 & 1 hour & 10 & 10 \\
2 & 1 hour & 11 & 14 \\
3 & 1 hour & 12 & 12 \\
4 & 1 hour & 6 & 4 \\
5 & 1 hour & 8 & 9 \\
6 & 1 hour & 3 & 3 \\
7 & 1 hour & 9 & 8 \\
8 & 20 minutes & 32 & 32 \\
9 & 20 minutes & 28 & 31 \\
10 & 10 minutes & 33 & 33 \\
\hline
\end{tabular}

bloods and that the effect of a definite (e.g., a $5^{\circ} \mathrm{C}$.) variation in temperature is greater as the temperature increases. Gordon and Cohn (16), using Linzenmeier's method, studied the sedimentation rates at $10^{\circ}, 23^{\circ}$, and $37^{\circ} \mathrm{C}$. and found startling differences in all the rates between these temperatures. They also found that the effect of external temperatures within these limits is transitory, i.e. that upon shaking and retesting the blood at a second temperature no influence of the original temperature will be apparent. These authors conclude that since the average room temperature varies between $22^{\circ}$ and $24^{\circ} \mathrm{C}$, a standard of $23^{\circ} \mathrm{C}$. should be maintained during the determination of the settling rate. 
We have determined the sedimentation by our method $^{3}$ on specimens of the same samples of blood at different temperatures varying from $20^{\circ}$ to $38^{\circ} \mathrm{C}$., and our findings in the main are similar to those noted above. Carefully regulated water baths were used for all the determinations, and the samples were allowed to rematin in the baths for 30 minutes before the tests were started in order to obtain temperature equilibrium. Chart 9 shows graphically the curves obtained in

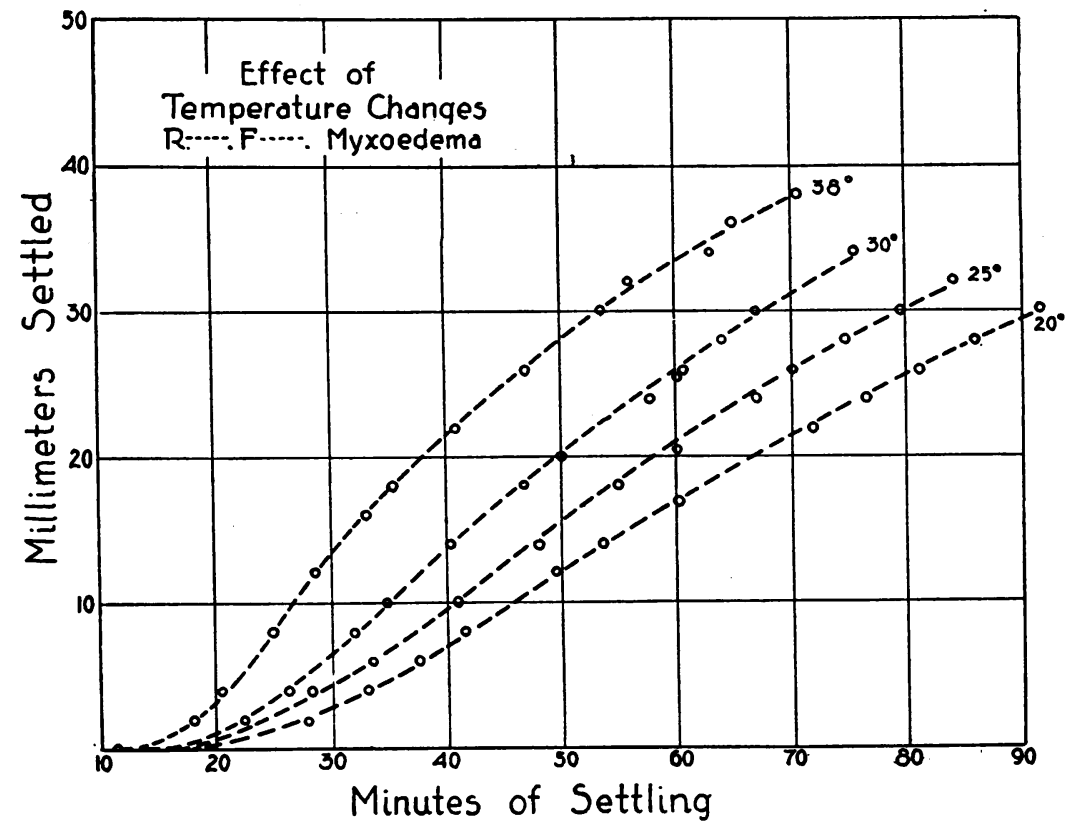

Chart 9. The Effect of Temperature Changes upon the Sedimentation RATE

a typical experiment where the blood was maintained at four different temperatures ranging from $20^{\circ}$ to $38^{\circ} \mathrm{C}$. The findings in 13 other experiments are presented in table 4 .

It is obvious that the settling rate increases to an appreciable extent with rising temperature within the range with which we are dealing, and that the increase in rate is less from $20^{\circ}$ to $25^{\circ}$ than from $25^{\circ}$ to

${ }^{3}$ Tubes giving a column of blood $100 \mathrm{~mm}$. high have been used for these temperature experiments. '(See J. Clin. Invest., 1928, v, 531.) 
$30^{\circ} \mathrm{C}$. Furthermore, the relative increase of rate per degree of temperature from $30^{\circ}$ to $38^{\circ}$ is greater than from $20^{\circ}$ to $25^{\circ}$ in the slowly settling specimens.

In more rapidly settling bloods, however, packing becomes such an important factor in the one hour readings at $38^{\circ}$ that the true temperature effect is masked and the curve falls off. In specimen 13, infectious arthritis, packing has almost entirely masked the temperature change.

TARLE 4

The effect of temperature changes on the sedimentation rate

\begin{tabular}{|c|c|c|c|c|c|c|}
\hline \multirow{2}{*}{ Subject } & \multirow{2}{*}{ Sex } & \multirow{2}{*}{ Diagnosis } & \multicolumn{4}{|c|}{ Millimeters settled in one hour at } \\
\hline & & & $20^{\circ}$ & $25^{\circ}$ & $30^{\circ}$ & $38^{\circ}$ \\
\hline I C. W. M. & M. & Normal & & & 2 & 3 \\
\hline II W. M. & F. & Normal & 2 & 2.5 & 4 & 6 \\
\hline III M. R. & M. & $\begin{array}{l}\text { 2nd and 3rd degree } \\
\text { burns }\end{array}$ & & & 6 & 11 \\
\hline IV D. G. & F. & Normal & 6 & 7 & 10 & 14 \\
\hline V Dog B & F. & Normal & & & 9 & 14 \\
\hline VI B. J. & M. & Normal & 9 & 11 & 15 & 20 \\
\hline VII R. R. & M. & Normal & 12 & & 19 & 23 \\
\hline VIII R. F. & F. & Myxedema & 17 & 20 & 26 & 34 \\
\hline IX B. M. & M. & Tuberculosis (mild) & 23 & 26 & 30 & 33 \\
\hline X L. G. & M. & Rheumatic fever & 28 & 32 & 39 & 40 \\
\hline XI H. H. & M. & $\begin{array}{l}\text { Arsphenamine derma- } \\
\text { titis }\end{array}$ & 37 & 39 & 46 & 48 \\
\hline XII R. F. & M. & Tuberculosis & 40 & & 46 & 48 \\
\hline XIII A. R. & M. & Infectious arthritis & 59 & 59 & 59 & 60 \\
\hline
\end{tabular}

We can not suggest the use of curves similar to those presented in chart 9 for correctional purposes, since the type of curve for rapidly settling bloods is dependent upon the relative importance of the packing factor, which would produce a greater straightening of the temperature rate curve for bloods with higher hematocrits (greater cell volumes).

For clinical work, we suggest that all tests be carried out at a room temperature of $20^{\circ}$ to $25^{\circ} \mathrm{C}$., since this range is not difficult to maintain in most laboratories, and since we feel that the variations in rate at such temperatures are not great enough to affect the value of 
the results. Any apparatus, which might be used to control the temperature more closely (constant temperature baths or rooms) would not be practical for clinical work, and so can not be advocated. However, if tests must be made under unusual temperature conditions, such as extreme summer heat, an attempt should be made to control the temperature between $20^{\circ}$ and $25^{\circ} \mathrm{C}$., or due allowance must be made in interpreting results. It is obvious that it is only in middle range (doubtful cases) that the effect of temperature changes might interfere with the interpretation of results.

THE EFFECT OF INGESTION OF FOOD UPON THE STABILITY OF THE BLOOD

Sedimentation rates and plasma protein fractions (Wu's (17) method) were determined upon blood samples from two subjects immediately before and shortly after the ingestion of food. In another experiment (no. 3), the sedimentation rate was determined at 1:1:00 a.m. and at 4:00 p.m., the subject not having eaten since 8:00 a.m. In the last experiment (no. 4) blood samples were taken for the determination of settling rates four hours after breakfast and again four hours after lunch on the same day.

The changes noted are quite insignificant and confirm DeCourcy's (7) observations. It seems doubtful whether there is any reason to prescribe that tests for clinical purposes should be run at any particular time of the day.

THE EFFECT OF SHORT, VIOLENT EXERCISE UPON THE SEDIMENTATION RATE

The effect of muscular exercise in concentrating the blood (increased plasma protein percentage and decreased plasma volume percentage) has been thoroughly studied by Scott, Hermann, and Snell (18), Peters, Bulger, Eisenmann, and Lee (19), and Rowe (20).

In view of this concentration, it would be reasonable to expect that there would be some alteration of the settling rate of the blood cells, but we can find no record of an experimental investigation of this point. Our experiments were made upon healthy, young individuals, blood samples being collected just before and immediately after the exercise period. Plasma proteins were determined by the method of $\mathrm{Wu}(17)$, the plasma carbon dioxide by the Van Slyke and Stadie. 
TABLE 5

Effect of ingestion of food upon stability of the blood

Experiment 1. E. S., normal young woman

\begin{tabular}{|c|c|c|c|c|c|c|}
\hline \multirow{2}{*}{ Specimen } & \multicolumn{4}{|c|}{ Plasma } & \multirow{2}{*}{$\begin{array}{c}\text { Cell } \\
\text { volume }\end{array}$} & \multirow{2}{*}{$\begin{array}{c}\text { Settling } \\
\text { after } \\
\text { hour }\end{array}$} \\
\hline & Fibrin & Globulin & Albumin & $\begin{array}{l}\text { Total } \\
\text { protein }\end{array}$ & & \\
\hline & per cent & per cent & per cent & per cent & per cent & \\
\hline $\begin{array}{l}\text { No. } 1-11: 30 \text { a.m., } 4 \text { hours after } \\
\text { breakfast. } \ldots \ldots \ldots \ldots \ldots \ldots\end{array}$ & 0.34 & 2.66 & 4.64 & 7.64 & 44.9 & 13 \\
\hline $\begin{array}{l}\text { No. } 2-1: 30 \text { p.m., } 1 \text { hour after } \\
\text { lunch. } \ldots \ldots \ldots \ldots \ldots \ldots \ldots\end{array}$ & 0.31 & 2.62 & 4.54 & 7.47 & 42.9 & 16 \\
\hline
\end{tabular}

Experiment 2. C. W. M., normal young man

\begin{tabular}{|c|c|c|c|c|c|c|}
\hline \multirow{2}{*}{ Specimen } & \multicolumn{4}{|c|}{ Plasma } & \multirow{2}{*}{$\begin{array}{c}\text { Cell } \\
\text { volume }\end{array}$} & \multirow{2}{*}{$\begin{array}{l}\text { Settling } \\
\text { after } \frac{1}{1} \\
\text { hour }\end{array}$} \\
\hline & Fibrin & Globulin & Albumin & $\begin{array}{c}\text { Total } \\
\text { protein }\end{array}$ & & \\
\hline & per cent & per cent & per cent & per cent & per cent & \\
\hline $\begin{array}{l}\text { No. } 1-11: 30 \text { a.m., } 3 \frac{1}{2} \text { hours after } \\
\text { breakfast. . . . . . . . . } \ldots \ldots \ldots\end{array}$ & 0.32 & 2.42 & 4.95 & 7.69 & 46.9 & 3 \\
\hline No. $2-1: 30$ p.m., 1 hour after & & & & & & \\
\hline lunch $\ldots \ldots \ldots \ldots \ldots \ldots$ & 0.30 & 2.60 & 4.93 & 7.83 & 45.0 & 3 \\
\hline
\end{tabular}

Experiment 3. M. D. R., normal young woman

\begin{tabular}{|c|c|c|}
\hline Specimen & $\begin{array}{c}\text { Cell } \\
\text { volume }\end{array}$ & $\begin{array}{c}\text { Settling } \\
\text { after } \frac{3}{2} \\
\text { hour }\end{array}$ \\
\hline & per cent & \\
\hline No. $1-11: 00$ a.m., 3 hours after breakfast. . & 42.7 & 14 \\
\hline No. $2-4: 00$ p.m., no lunch, 8 hours after breakfast. & 43.2 & 17 \\
\hline
\end{tabular}

Experiment 4. E. L. M., normal young woman

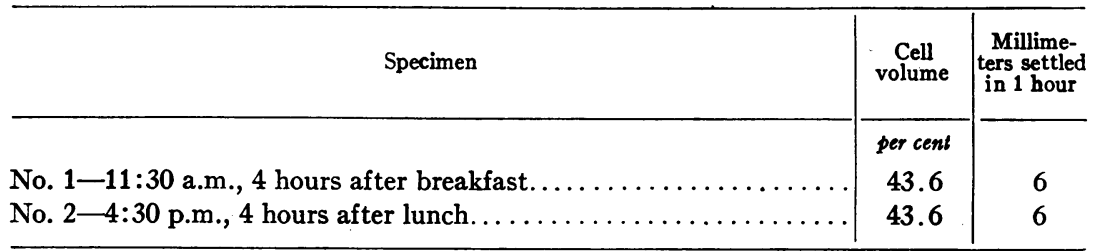

procedure (21), and the sedimentation rate and cell volume on heparinated blood according to our own technic.

Short, violent exercise of this nature tends to concentrate the blood, 
increasing the plasma protein percentage, which should, according to our concept, make for more rapid settling of the cells, and at the same time increasing the cell volume percentage, which should retard sedimentation. The observed decrease in the carbon dioxide content of the plasma should have no appreciable effect on the sedimentation

TABLE 6

Effect of exercise upon the sedimentation rate

Experiment 1. R. L. J., a healthy young man ran up and down four flights of stairs four times, taking three minutes for the task, and being quite exhausted at the end:

\begin{tabular}{|c|c|c|c|c|c|c|c|}
\hline & \multicolumn{4}{|c|}{ Plasma } & \multirow{2}{*}{$\begin{array}{c}\mathrm{CO}_{2} \\
\text { content }\end{array}$} & \multirow{2}{*}{$\begin{array}{c}\text { Heparin } \\
\text { cell } \\
\text { volume }\end{array}$} & \multirow{2}{*}{$\begin{array}{l}\text { Settled in } \\
1 \text { hour }\end{array}$} \\
\hline & Fibrin & Globulin & Albumin & $\begin{array}{c}\text { Total } \\
\text { protein }\end{array}$ & & & \\
\hline & per cont & per cent & per cent & per cent & $\begin{array}{l}\text { volumes } \\
\text { per cent }\end{array}$ & & \\
\hline Before exercise..... & 0.25 & 2.10 & 4.80 & 7.15 & 49.0 & 45.5 & 6 \\
\hline After exercise......... & 0.27 & 2.32 & 4.95 & 7.54 & 38.0 & 48.0 & 8 \\
\hline
\end{tabular}

Experiment 2. M. D. R., a healthy young woman, ran up and down three flights of stairs six times in four minutes.

\begin{tabular}{|c|c|c|c|c|c|c|}
\hline & \multicolumn{4}{|c|}{ Plasma } & \multirow{2}{*}{$\begin{array}{c}\text { Heparin } \\
\text { cell } \\
\text { volume }\end{array}$} & \multirow{2}{*}{$\begin{array}{l}\text { Settled in } \\
1 \text { hour }\end{array}$} \\
\hline & Fibrin & Globulin & Albumin & $\begin{array}{c}\text { Total } \\
\text { protein }\end{array}$ & & \\
\hline & per cent & per cent & per cent & per cent & & \\
\hline Before exercise. . & 0.31 & 2.12 & 4.40 & 6.85 & 45.6 & 7 \\
\hline After exercise........... & 0.35 & 2.22 & 4.68 & 7.25 & 48.1 & 6 \\
\hline
\end{tabular}

Experiment 3. P. M. H., a healthy young woman ran up and down three flights of stairs three times in two minutes.

\begin{tabular}{|c|c|c|}
\hline & $\begin{array}{c}\text { Heparin } \\
\text { cell } \\
\text { volume }\end{array}$ & $\begin{array}{l}\text { Settied in } \\
1 \text { hour }\end{array}$ \\
\hline 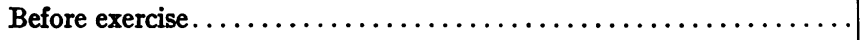 & 40.4 & 11 \\
\hline 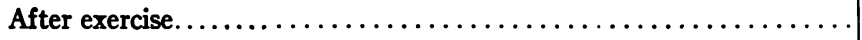 & 44.2 & 11 \\
\hline
\end{tabular}

velocity, according to the studies of Ito (15). Assuming that other factors, such as increased lactic acid, have relatively negligible effects, it would seem that, in the experiments noted, the increase in plasma proteins, particularly the fibrin fraction, produces an accelerating effect, which is approximately (in experiment 3 exactly) equalized 
by the retarding effect of the increase in cell volume percentage. The subject warrants more study, but in the light of these experiments, we feel that the sedimentation velocity of the blood cells could not be altered materially by any usual state of activity of the individual.

\section{CONCLUSIONS}

1. Heparin is the ideal anticoagulant for blood sedimentation studies, since it has no effect on the settling rate other than keeping the blood from clotting. The inorganic anticoagulants depress the rate of settling in proportion to their concentration. Dilution with the citrate solution described in Linzenmeier's technic slows the rate to a greater extent than does the dry salt.

2. Aggregation of the red blood cells under conditions obtaining in sedimentation tests is a completely reversible phenomenon. Blood may usually stand at room temperature for six to twelve hours without the sedimentation rate being affected materially, whereas longer standing generally leads to a slowing of the rate. All tests should be completed on the day when the blood is drawn.

3. Centrifuging blood for 20 minutes at 2500 r.p.m. does not affect its settling velocity after remixing.

4. Blood dilution (with its own plasma) leads to more rapid settling of the cells. In samples where the aggregating and packing factors are not largely operative this change is represented by a straightline curve.

5. Aeration of venous blood has no significant effect upon the rate of settling, therefore the collection of blood samples under oil is not necessary.

6. Increase of temperature (within certain limits) makes for more rapid sedimentation. Within the range of ordinary room temperatures, the changes are hardly significant.

7. The changes in rate of settling due to the ingestion of food are slight and may be disregarded for ordinary work.

8. Short, violent exercise has an insignificant and variable effect on the sedimentation rate. The accelerating effect of the fibrnnogen increase is compensated by the retarding effect of the increase in cell volume. 


\section{BIBLIOGRAPHY}

1. Fahraeus, R., Acta Med. Scandinav., 1921, lv, 1. The Suspension-Stability of the Blood.

2. Popper, M., and Kreindler, F., Ann. de Méd., 1925, xvii, 57. La vitesse de sédimentation des hématies. Abst. in J. Am. Med. Assoc., 1925, lxxxv, 1925.

3. Linzenmeier, G., Arch. f. Gynäk., 1920, cxiii, 608. Also, Arch. f. d. ges. Physiol., 1920, clxxxi, 169. Untersuchungen über die Senkungsgeschwindigkeit der roten Blutkörperchen.

4. Oliver, J., and Barnard, L., J. Gen. Physiol., 1924-25, vii, 99. The Influence of Electrolytes on the Stability of Red Blood Corpuscle Suspensions.

5. Pohle, E. A., Radiology, 1926, vi, 55. Studies on the Suspension Stability of the Human Blood. II. The Changes of the Sedimentation Rate of the Erythrocytes in Vitro and in Vivo after X-ray Exposure.

6. Westergren, A., Ergebn. d. inn. Med. u. Kinderh., 1924, xxvi, 577. Die Senkungsreaktion. Allgemein-klinische Ergebnisse. Praktische Bedeutung bei Tuberkulose.

7. Wiltshire, H., J. Path. and Bact., 1912-13, xvii, 282. An Investigation into the Cause of Rouleau Formation by Human Red Blood Corpuscles.

8. DeCourcy, J. L., Am. J. Surg., 1925, xxxix, 129. Value of Blood Settling Time in Goiter.

9. Guthmann, H., and Schneider, G. H., Arch. f. Gynäk., 1925-26, cxxvii, 515. Die diagnostische und prognostische Bedeutung der Blutkörperchensenkungsgeschwindigkeit beim Carcinom.

10. Gram, H. C., Arch. Int. Med., 1921, xxviii, 312. On the Causes of Variations in the Sedimentation of the Corpuscles and the Formation of the Crusta Phlogistica ("Size," "Buffy Coat") on the Blood.

Gram, H. C., Acta Med. Scandinav., 1928, lxviii, 108. Ueber die Correction der Senkungsreaktion für den Einfluss des Zellvolumenprocentes (Haemoglobin) und über die normalen Grenzen der Senkungsreaktion.

11. Bönniger, M., and Herrmann, W., Klin. Wchnschr., 1923, ii, 744. Blutkörperchensenkungsgeschwindigkeit und -Volumen.

12. Rubin, E. H., and Smith, N. N., Arch. Int. Med., 1927, xxxix, 303. Relation of Hemoglobin, Cell Count and Cell Volume to the Erythrocyte Sedimentation Reaction.

13. Hubbard, R. S., and Geiger, H. B., J. Lab. and Clin. Med., 1928, xiii, 322. Anemia as a Factor in the Sedimentation Time of Erythrocytes.

14. Westergren, A., Acta Med. Scandinav., 1920-21, liv, 247. Studies of the Suspension Stability of the Blood in Pulmonary Tuberculosis.

15. Ito, W., Tohoku J. Exper. Med., 1924, v, 139. Über den Einfluss der Blutgase (des Sauerstoffs und der Kohlensäure) auf die Senkungsgeschwindigkeit der Erythrozyten. 
16. Gordon, M. B., and Cohn, D. J., Am. J. Med. Sci., 1928, clxxvi, 211. The Effect of External Temperature on the Sedimentation Rate of the Red Blood Corpuscles.

17. Wu, H., J. Biol. Chem., 1922, li, 33. A New Colorimetric Method for the Determination of Plasma Proteins.

18. Scott, F. H., Herrmann, E. T., and Snell, A. M., Am. J. Physiol., 1917, xliv, 313. Factors Influencing the Interchange of Fluid between Blood and Tissue Spaces. II. Muscular Activity.

19. Peters, J. P., Bulger, H. A., Eisenman, A. J., and Lee, C., J. Biol. Chem., 1926, lxvii, 175. Total Acid-Base Equilibrium of Plasma in Health and Disease. IV. The Effects of Stasis, Exercise, Hyperpnea, and Anoxemia; and the Causes of Tetany.

20. Rowe, A. H., Arch. Int. Med, 1917, xix, 499. The Effect of Muscular Work, Diet and Hemolysis on the Serum Proteins Together with Comment on the Technic and Clinical Usefulness of Robertson's Microrefractometric Method.

21. Van Slyke, D. D., and Stadie, W. C., J. Biol. Chem., 1921, xlix, 1. The Determination of the Gases of the Blood. 